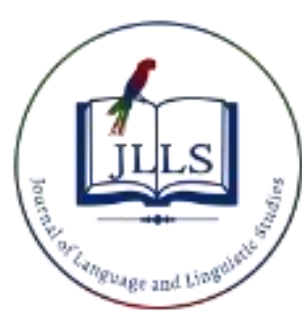

Available online at www.jlls.org AND LINGUISTIC STUDIES

ISSN: $1305-578 \mathrm{X}$

Journal of Language and Linguistic Studies, 16(2), 595-611; 2020

\title{
Identifying the needs of postgraduate students: The first step of academic writing courses
}

\author{
Fatma Yuvayapan a 1 (D), Hayriye Bilginer $^{\mathrm{b}}$ \\ ${ }^{a}$ Kahramanmaras İstiklal University, Kahramanmaras, Turkey \\ ${ }^{b}$ Kahramanmaraş Sütçü İmam University, Kahramanmaraş,, Turkey

\section{APA Citation:} \\ Yuvayapan, F. \& Bilginer, H. (2020). Identifying the needs of postgraduate students: The first step of academic writing courses. Journal of \\ Language and Linguistic Studies, 16(2), 595-611. \\ Submission Date: $15 / 01 / 2020$ \\ Acceptance Date:18/05/2020
}

\begin{abstract}
Academic writing practices constitute central processes through which students learn the conventions of their disciplines to meet the expectations of their academic communities. Therefore, academic writing courses should touch on the specific dimensions of it. One of the most prominent requirements of these courses is to identify the needs of students and implement a program based on the negotiation between the needs of students and the expectations of academic communities. The present study aimed to explore the academic writing needs of Turkish postgraduate students in the departments of English Language Teaching and English Language and Literature through an online questionnaire including Likert-type items and open-ended questions. The Likert-type items were analyzed using descriptive statistics and independent samples t-test statistics while the data gathered from openended questions was exposed to thematic analysis. We found that the participants (30 Turkish postgraduate students of English) obtained a clear idea of the disciplinary conventions and the importance of communication with readers in academic genres but they did not seem to develop awareness of building stance in academic genres. There was not a statistical difference between MA and $\mathrm{PhD}$ students' academic writing needs. Apparently, academic writing courses in post-graduate programs should place heavy demands on more specific needs-based curriculum to meet their students' target needs.
\end{abstract}

(C) 2020 JLLS and the Authors - Published by JLLS.

Keywords: Postgraduate programs; academic writing; needs analysis

\section{Introduction}

Academic writing (AW) is now a well-researched area in the literature owing to the fact that English is the lingua-franca of international academic world and it is a must for academics to be competent in writing in English. In this world, academics are expected to tackle with native-like academic writing demands of their disciplines: using linguistic features of English for a persuasive representation of their studies and mitigating a credible academic identity. As a result, English has become the medium of instruction for both graduate and post-graduate studies in many countries. Especially, post-graduate students attend AW courses to improve their academic knowledge and skills. Buckingham (2008)

\footnotetext{
${ }^{1}$ Corresponding author. Tel.: +0-344-300-4981

E-mail address: fyuvayapan@gmail.com
} 
explains the interest in the study of nonnative speakers' writing ability: the increase in the number of students enrolling Anglophone tertiary institutions and the trend in writing doctoral dissertations in English.

To comprehend the necessities of AW courses in this international academic world, it may be beneficial to get a clear picture of what AW means. The definitions provided by the scholars in the literature reflect different dimensions of AW: a tool to get credibility in academic community, a representation of disciplinary-based academic knowledge and interaction with readers. As for Hyland (2009) academic discourse is "ways of thinking and using language which exist in the academy" (p. 1). Irvin (2010) defines AW as "the form of evaluation that asks you to demonstrate knowledge and show proficiency with certain disciplinary skills of thinking, interpreting and presenting" (p. 8). For Burke (2010), it refers to "what academics do most, through publishing, communicating, and contributing to their knowledge" (p. 40).

In the now globally English-oriented academic world, AW goes beyond advanced writing in English that is mostly rested on the employment of appropriate linguistic features. As Hyland (2004) states, the success of AW is closely associated with "the individual writers' projection of a shared professional context" (p. 1). They scaffold their writing with a specific social world with the use of approved discourses. Hence, it is a pedagogical imperative for academic writing courses to highlight different dimensions of AW, which are disciplinary-based, socially constructed and genre-specific.

Feak (2016) claims that there has been a mismatch among the course content, the research and AW needs of postgraduate students since 1980s. Tait (1999) alleges that EAP (English for Academic Purposes) courses are designed to meet so-called needs of nonnative students of English. As Klimova (2014) suggests, EAP teachers should basically identify students' learning needs and design a course to meet these needs. In other words, doing a needs analysis is essentially the first of step of EAP courses. Some attempts have been made to identify the conceptions of AW (Ma, 2018); the AW needs of postgraduate students in particular disciplines and programs (Al-Khasawneh, 2010; Cai, 2017; Huang, 2010) and the problems in thesis writing (Bitchener \& Basturkmen, 2006). As Long (2005) states, all courses need to be implemented rested on the needs of specific groups of learners and society. To our knowledge, very little is known about the academic writing needs of postgraduate students in Turkish context. Hence, this study is an attempt to identify the academic writing needs of Turkish postgraduate students in the departments of English Language Teaching and English Language and Literature through a questionnaire.

\subsection{Literature review}

Different dimensions of AW place extra burden on nonnative academics by academic communities where it is noteworthy competence for them to construct their stance, to communicate with readers and more substantially to get a credible place in that community through appropriate employment of disciplinary and genre-based linguistic conventions. To foster this competence in AW in English, they start with attending AW courses in their postgraduate studies offered by their universities. However, they might come across with some difficulties in AW during their postgraduate studies.

AW causes difficulties for nonnative speakers of English for a variety of reasons. Hyland (2009) highlights the difficulties that nonnative students face while writing academic texts. The style of writers in this specific form of writing is shaped by the linguistic norms of disciplines and cultures. For many nonnative students of English, these norms are difficult and challenging, which forces them to be more cautious in representing the content and their presence. Additionally, they are so concerned with the organizational issues and establishing writer-reader interaction that they may not be able to supplement propositional information effectively. Cameron, Nairn and Higgins (2009) draw our attention to an 
emotional perspective. Due to the lack of experience, novice academic writers have some emotional handicaps of writing. They are so concerned with linguistic conventions that they cannot convey the truth of propositional content, which make them doubt about their knowledge about the topic. On the other hand, for experienced writers, these conventions are just a means to represent the content in a recursive way.

In order to cope with the difficulties mentioned above, AW courses should be implemented carefully regarding the materials, the dimensions of $\mathrm{AW}$ and the assessment techniques and most prominently the particular needs of postgraduate students attending the course. Hence, needs analysis is a prerequisite for conducting an AW course. Brown (1995) describes needs analysis as the process of gathering information to implement a curriculum that meets the needs of learners. This process consists of three basic steps:

- Making basic decisions: In this step, the preliminary decisions are made about the stakeholders, the type of information that will be gathered and the underlying points of view and the philosophy.

- Gathering information: is rested on five categories of questions: problems, priorities, abilities, attitudes and solution. The role of the needs analyst (insider or outsider) influences the types of instruments to be used in the process. Existing information, tests and observation are the tools that require the need analysts to be an outsider but they are insiders while conducting interviews, meetings and questionnaires.

- Using information

He also summarizes four philosophies underlying needs analysis: In the discrepancy philosophy, needs are determined by identifying what students are actually doing and what their expected performances are. The desired changes in the performances of a majority of the group is the basis of democratic philosophy. The analytic philosophy refers to scaffolding what students already know and what they should learn. A diagnostic philosophy emphasizes a need that may be harmful if it is missing.

A search of the literature revealed few studies concerned with AW needs of postgraduate students. Al-Khasawneh and Maher (2010) attempted to explore AW problems of Arab postgraduate students at a Business Department through face-to-face interviews and reported that vocabulary register, organizational issues, grammar, spelling and referencing are the problem areas for these students. In another study, Cai (2017) conducted a needs analysis with 50 MA students in English attending at an EAP course in China through a survey and found that $70 \%$ of students thought that this course did not meet their AW needs. They expressed their desire to engage in an AW course centered on the generic features of academic genres. Ma (2018) specifically focused on the L2 post-graduate students' conceptions of AW and found that students considered AW as a domain of advanced general writing in English and self-directed practices are beneficial for them to improve their AW skills and knowledge.

Bitchener and Basturkmen (2006) focused on the writing difficulties of L2 students in improving finding sections of their theses and compared the perceptions of students with their supervisors. The results revealed a limited understanding of the function of this section from students' perspectives. In another study, Huang (2010) compared AW needs of graduate and undergraduate students from students' and instructors' perspectives in the context of an academic language support center at a Canadian university. The results indicated shared perceptions between students and instructors regarding AW needs to complete the program.

Tait (1999) summarizes the approaches to identify AW needs of non-native students of English. He claimed that current studies used limited number of approaches and sources as data collection tools and closed questionnaire could not assist us to figure out the real attitudes of participants but simply direct them to answer about certain structures. They also followed an objective approach that is lack of critical 
evaluation of the situation. Emphasizing the complexity in the determining common AW needs, he suggested to specify various academic needs of particular groups resulted from individual differences.

Overall, the success in AW is the foundation of being competent academics. Postgraduate students as novice academics struggle with not just the linguistic norms of AW but with building their presence and pulling their readers into their texts during their post-graduate studies. Thus, they need academic guidance to overcome these challenges, which can be best supplied with AW courses rested on their specific academic needs. To do this, we should first address these needs to implement a curriculum for academic writing courses.

\subsection{Research questions}

It is now well-established that AW is bound to disciplinary linguistic features and AW courses need to consider these features. It is also necessary to know about learners' needs while implementing such courses. Since AW is disciplinary-based, a needs analysis should focus on the learning needs of particular group of students in a particular field. There has been little data on AW needs of Turkish postgraduate students in the departments of English Language Teaching and English Language and Literature. Given the paucity of information in the literature, this study was undertaken to address the following research questions:

1. How do Turkish postgraduate students in the departments of English Language Teaching and English Language and Literature perceive academic writing?

2. What academic writing skills do Turkish postgraduate students in the departments of English Language Teaching and English Language and Literature need to improve?

2a. What types of course activities do they prefer to engage in academic writing courses?

3. Is there a significant difference between the academic writing needs of MA and $\mathrm{PhD}$ students in the departments of English Language Teaching and English Language and Literature?

\section{Method}

Following an analytic philosophy of needs analysis, the present study will explore what post-graduate students already know and then we will discuss what AW courses should include to assist them to be successful academics.

\subsection{Participants}

The participants of the study involved $30 \mathrm{MA}$ and $\mathrm{PhD}$ students who were studying at the postgraduate programs of the departments of English Language Teaching and English Language and Literature at state and private Turkish universities. They enrolled in postgraduate programs of 16 Turkish universities and consisted of $36.7 \%$ males and $63.3 \%$ females. 13 of them were between the ages of 22-30 years and 17 of them were above 30 years. $50 \%$ of them were MA students and the rest were at different stages of obtaining doctoral degree. $37 \%$ of them enrolled an AW course at the undergraduate level; $60 \%$ stated that they took an AW course at MA level while $3 \%$ had no AW course in their postgraduate studies.

\subsection{Instrument}

Aiming to figure out the AW needs of postgraduate students, the study obtained data that was primarily based on an online questionnaire available at 
https://docs.google.com/forms/d/130g5AyearvFhCr0DqQzVs5PmDeumlwU1NkIEWyZyQf8/edit. Google Form Tool was used to administer the questionnaire to the participants. The researchers created the questionnaire (See Appendix 1) by utilizing some items of a survey suggested by Chou (1998) and an online survey available at https://www.sheffield.ac.uk/polopoly_fs/1.92335!/file/needsanly.rtf. The questionnaire mainly consisted of five-point Likert-type items ranging from 1 (Strongly disagree) to 5 (Strongly Agree). Some questions that were in an open-ended format were added to expand and clarify on the Likert-type items on the suggestion of an expert who did $\mathrm{PhD}$ in the field of English Language Teaching. As Bolarinwa (2015) suggests, asking an expert on the research subject to review the questionnaire is a means of constructing validity of questionnaires.

The first section of the survey was associated with the demographic information about the participants. The second section included two open-ended questions to elicit data about the definition of AW and the feelings of the participants about AW. The third section dealt with the needs of Turkish postgraduate students in terms of academic genres. This section included seven questions using a fivepoint Likert scale. An open-ended question about the importance of readers in academic genres was put at the end of this section. In the fourth section that comprised of 10 five-point Likert-type items, it was aimed to figure out the needs of the participants about the moves of academic genres. The fifth section, which was concerned with the questions of cohesion in academic texts, had 17 five-point Likert-type items. There were 12 three-point Likert-type items in the last section ranging from 1 (little time) to 3 (a little time) and it tapped into participants' perceptions about the frequency of teaching activities implemented in AW courses.

After the data were collected, the instrument underwent internal reliability test. Cronbach's alpha was computed for the Likert-type sections to evaluate the internal consistency reliability. The results showed that the survey had a high level of reliability at $\alpha=.962$. In addition, the Cronbach Alpha of each Likert-type item was also computed above .9. As Pallant (2005) states, the ideal Cronbach alpha of a scale should be above.7.

\subsection{Data collection procedures}

To distribute the questionnaire, invitations e-mails were sent to some academics and the head of the departments of English Language Teaching and English Language and Literature and they were kindly asked to forward the link of the questionnaire to their $\mathrm{MA}$ and $\mathrm{PhD}$ students. A total of 30 postgraduate students who were doing their studies at MA and PhD programs of the departments of English Language Teaching and English Language and Literature answered the survey through Google Form.

\subsection{Data analysis}

Several types of analyses were conducted in this study. SPSS Version 22 was used to perform the Cronbach Alpha and independent samples t-test. In order to ensure the reliability of each item of the survey, Cronbach Alpha Coefficient was calculated and independent samples t-test was conducted to compare whether there was a significant difference between AW needs of MA and PhD students. As Pallant (2005) explains, this test is used "to compare the mean score, on some continuous variable, for two different groups of subjects" (p. 205).

To calculate the percentages of each Likert-type item, descriptive statistics was applied. The response continuum for each question in Section 3, 4 and 5 was a five-point Likert scale indicating the extent the participants agree or disagree with the statement. However, while presenting the results, summative scales were applied. Likert scaling was reduced to three (Disagree, Neutral and Agree). The item responses of 1 (Strongly disagree) and 2 (Disagree) were summed and the items 4 (Agree) and 5 
(Strongly Agree) were treated as single data. The data analysis related to Section 6 centered on threepoint Likert scale (1 little, 2 sometime and 3 a little time).

The open-ended questions in Section 2 were exposed to thematic analysis. This analysis includes 3 stages:

- Descriptive coding: identifying descriptive codes

- Interpretative coding: interpreting the codes in relation to research questions

- Overarching themes: deriving key themes for data set as a whole (King and Horrocks, 2010, p. 153).

In this study, two researchers did the coding of the answers and interpreted them based on the research questions individually and then we discussed the two analyses to reveal the key themes.

\section{Results}

The first research question aimed to explore how Turkish postgraduate students in the departments of English Language Teaching and English Language and Literature perceive academic writing (AW). As stated in the methodology part, Section 2 in the questionnaire included two open-ended questions to answer this research question. The first question was concerned with the definition of AW and the thematic analysis of the replies of this question revealed three themes regarding the definition of AW:

- the conventions of academic writing

- interaction with the audience

- the disciplinary-based features of academic writing

The most common theme emerged from the data was associated with the conventions of $A W$ in terms of the organization and cohesion as can be inferred from the quotation below. This theme might indicate that most of the participants were aware of the fact that $\mathrm{AW}$ requires careful attention to some agreed conventions of their disciplines. Ma (2018) observed that postgraduate nonnative students of English consider AW as an advanced form of general English associated with certain features such grammar, vocabulary and text organization.

Academic writing is a kind of genre that requires certain structural, organizational and stylistic rules and tendencies to follow in order to be able to produce academic writings such as dissertations, research articles and so on (Participant 7).

The second theme was about interaction with audience. As seen in the quotation below, some of the definitions highlighted the importance of persuading readers and presenting arguments in an accepted manner by readers in AW. For academic writers to influence their fields and become a member of their academic communities, they must engage their readers into their texts and gain acceptance of their readers about the truth of their claims. In this sense, developing a sense of audience is crucial for them.

Being able to define, express, and explain in an organized written form to persuade or inform the reader (Participant 2).

This quotation below draws our attention to the disciplinary-based features of $A W$, which was the third theme in terms of the definition of AW in the lens of the participants. This theme indicated the participants' understanding of their discourse communities. AW provides a link between writers and their disciplinary communities through shared norms and values.

It is a style of formal expression that researchers use to define their intellectual boundaries of their professional field (Participant 17). 
Apparently, the definitions provided by the participants focused on different features of AW: linguistic conventions, readers' expectations and norms of the disciplines. Their understanding of AW was mostly centered on the demands of the discipline and the expectations of readers. Feak (2016) explains the challenges that postgraduate students face with in their academic communities: the lack of background knowledge on the discipline they enter, and comprehending the concept of audience in interdisciplinary work. The participants in our study seemed to consider AW as an impersonal form of writing accomplished through a wide range of linguistic devices. They also employed these features for the purposes of communicating with their readers and organizing their texts.

The success of postgraduate students in their discipline is determined by what they write and whether their readers who are highly proficient academics in their disciplines accept it. Hence, the concentrations on the linguistic norms that meet the expectations of readers and the discipline are crucial for them. However, one immediately prominent feature of AW and one which was ignored by the participants of this study is stance-taking that is built up through the purposeful employment of various language features. Constructing strong stance is the key to get credibility in academic communities. As Hyland (2002) states, AW is not merely presenting the ideational content but representing the self. Stance in academic texts is built by consistent language choices and its success depends on the extent it is accepted by the readers in that discipline (Hyland, 2010).

In the second question of Section 2, we intended to comprehend their feelings towards AW. The themes emerged from the analysis of replies related to this question were:

- overcoming the difficulties of AW through practice

- deciding the content

- determining appropriate words

- success and satisfaction

The first theme highlighted the importance of practice in overcoming the difficulties of $A W$. Some participants found it challenging but as they gained insights into the complexities of AW through practice, they gradually shifted away from them. As can be understood from the quotation below, academic practice was a powerful means of mastering the difficulties of this form of writing.

At the very beginning of the post-graduate program, I remember I felt nervous about it. However, I start to feel comfortable and relaxed as I have gained experience in writing academic texts, especially after I completed my MA thesis and following articles. Moreover, I feel more secure about academic writing as I read more and more well-written articles about my field (Participant 1).

The quotation below focused on another difficulty related to AW: deciding the content. As Murray and Moore (2006) explain, starting to write an academic paper requires different skills from finishing it, which is the first paradox in AW.

I get distressed when I begin to think about what I am going to write (Participant 19).

The second paradox is called as "the originality versus convention paradox". The conventions of expressing ideas or arguments in AW sometimes make academic writes feel less confident about presenting their ideas and constructing their stance. This paradox can be clearly understood from the quotation below, which reflected the third theme regarding the difficulties of AW in our study: determining appropriate words.

I feel more stressful, it is hard to decide on words or phrases in academic writing in order not to make mistake. (Participant 21).

The last one reflects another paradox in AW: "the logic versus emotion". The successful completion of academic texts ends in satisfaction and joy for writers. As can be inferred from the quotation below, success in academic genres led to satisfaction for some of the participants in this study. 
It is a bit like working out; difficult to do but you feel great afterwards (Participant 30).

These findings are in line with some studies in the literature. Sağlamel \& Kayaoğlu (2015) who examined the perceptions of English major students towards AW courses, found that students did not feel comfortable while engaging in AW activities although they admitted the importance of it for their graduate studies and future career. They further contended that the mastery of writing can be gained through practice.

Now that we explained what AW means for the postgraduate students of English in this study, we can move on explaining the results associated with the second research question that is about Turkish postgraduate students' needs of AW in terms of genres, sections and language areas of these genres. They informed us that they expected to write theses, articles, reviews, book chapters, posters and conference speech. As Feak (2016) states, there has been a continuing need of postgraduate students on genre and sub-genre issues. They need support on how to write theses, book reviews, articles, literature reviews as well as developing their speaking skills to make conference speech and defense of a thesis. As displayed in Figure 1, over half of the participants reported that they needed instruction on writing a thesis (63\%), a book review (62\%) and a research article (50\%) and a conference speech (50\%). They seemed to confront with two specific academic genres: writing a term paper and a response paper.

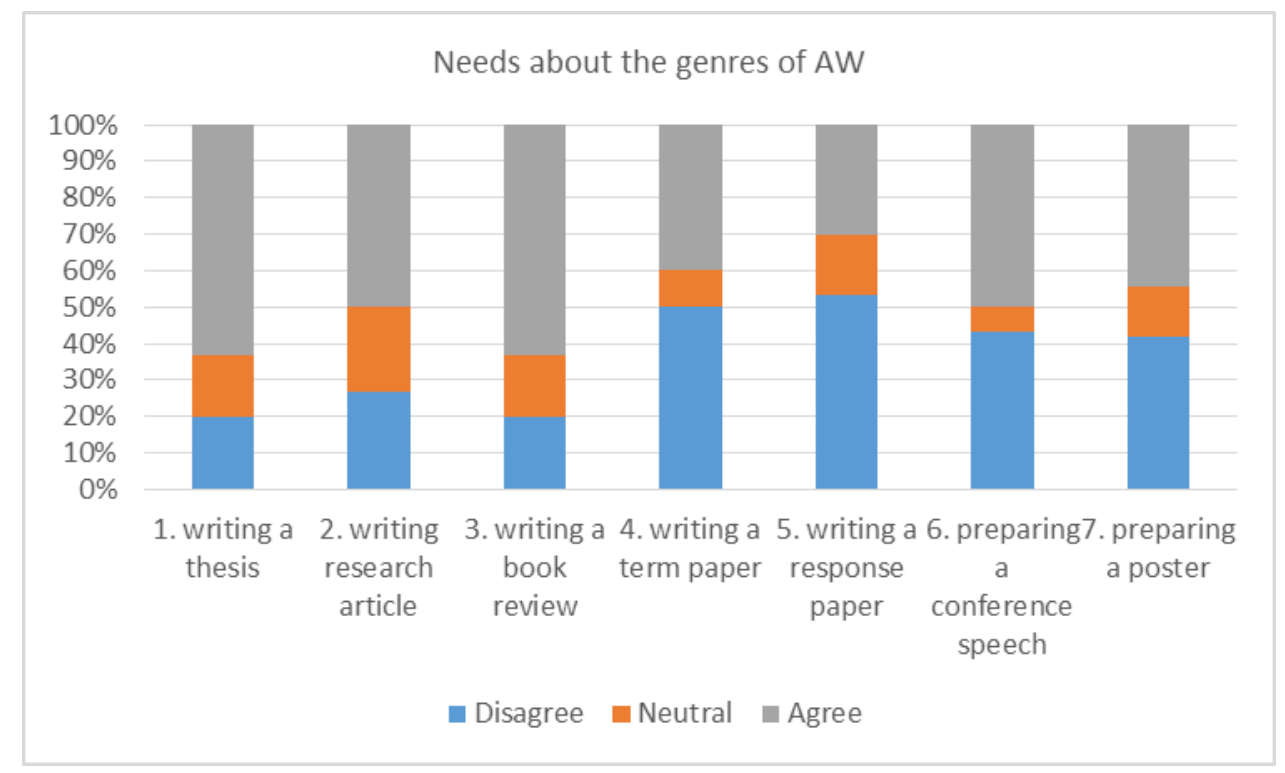

Figure 1. Turkish postgraduate students' needs regarding the types of AW genres

Writing a thesis is probably the most challenging work of research a postgraduate student has ever finished. Hence, it is not surprising that the participants emphasized a need for guidance while writing their thesis. What is striking is the demand of instruction on writing a book review. Although research papers are one of the most common genres of academic discourse, the participants seemed to give more prominence on writing a book review. It is likely that, they were not familiar with the conventions of a book review, so they need guidance on this issue.

In this section, the last question was an open-ended question aimed to figure out whether they thought about their readers while writing the genres above. Only four participants reported that they did not focus on the expectations of their readers. A great majority of them showed an understanding of their readers' expectations. They clearly kept their audience in mind and made rhetorical decisions to pull their readers into their academic texts. This finding is in line with some studies. In Huang's (2010) study, the majority of the graduate students felt that showing an awareness of readers' needs has a significant 
impact on their academic success. It is likely that they sought to offer a credible presentation of the content by establishing solidarity with their readers. Hyland (2001) claims that academic writers need to marshal their arguments and present the results and interpretations in a way that is credible and persuasive for their readers.

Figure 2 illustrates the participants' needs about the parts of academic texts. The main motivations were the need to write discussions (63\%) and write findings with clarity $(63 \%)$, which may be attributed to the fact that researchers need to construct a critical stance between their findings and previous studies to convince their readers about the truth of their claims. In addition, these parts demonstrate writers' ability to fill the existing gaps in the field. These factors may explain why the participants needed instruction on writing these sections. Li and Vandermensbrugghe (2011) claim that the ability to write with clarity and confidence is one of the biggest obstacles for nonnative academic writers. Being able to write clear methodology sections $(57 \%)$ was also considered as an important issue for the participants of this study. This section also requires a persuasive style in which researchers demonstrate that the way they conduct their studies is appropriate. The importance of writing appropriate literature reviews (50 $\%)$, introductions $(50 \%)$, conclusions (50\%) and suggestions and implications (53\%) was also recognized by the participants. They seemed to feel capable of writing references (37\%) and abstracts (40\%). These results are in line with some studies. In Cai's (2017) study, the participants reported their willingness to take a new AW course that enables them to write different sections of academic texts effectively.

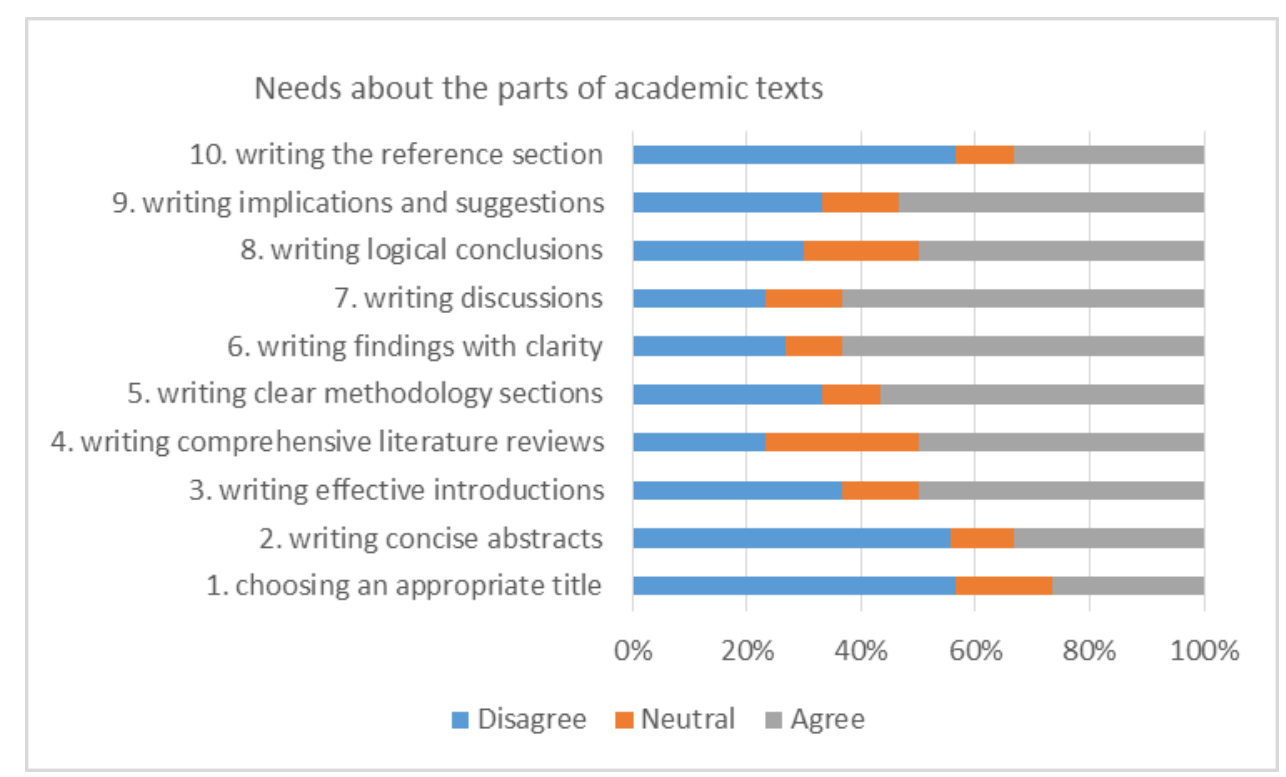

Figure 2. Turkish postgraduate students' needs regarding the sections of AW genres

Table 1 illustrates the needs of the participants in terms of language areas in academic genres. Most of the items in this section were rated quite low, which showed that the participants did not have trouble about applying the appropriate linguistic features of their discipline. Specific problems mentioned in this section were: avoiding plagiarism (48 \%), the correct use of citation $(40 \%)$, paraphrasing and the appropriate use of vocabulary (33\%). Tait (1999) emphasizes that understanding the concept of plagiarism is a fundamental academic writing need of ESL students. Although the appropriate use of grammatical and lexical features had low percentages in our study, they are usually recognized as problematic in some studies. Cai (2017) observed that MA students found choosing appropriate lexical items in academic texts very difficult. 
In academic communities, writers are bound by particular responsibilities one of which is avoiding plagiarism. Maybe, it is the most serious ethical misconduct recognized in academic conventions. In this study, the participants reported that they should be provided guidance on the procedures of avoiding plagiarism. Another point they emphasized was referencing conventions of their disciplines, which are closely related to plagiarism. It seems that these procedures must be stressed in AW courses especially in the fields of English Language Teaching and English Language Literature because English is a second language for the students studying in these fields. The conventions of plagiarism and referencing have also different underlying principles in English.

Table 1. Postgraduate students' needs regarding the language areas of AW genres

\begin{tabular}{|c|c|c|c|}
\hline & $\begin{array}{l}\text { Disagree } \\
\%\end{array}$ & $\begin{array}{c}\text { Neutral } \\
\%\end{array}$ & $\begin{array}{l}\text { Agree } \\
\%\end{array}$ \\
\hline $\begin{array}{l}\text { 1. I need instruction on using topic sentences in } \\
\text { paragraphs. }\end{array}$ & 70 & 10 & 20 \\
\hline $\begin{array}{l}\text { 2. I need instruction on giving enough supporting } \\
\text { details or examples in body paragraphs. }\end{array}$ & 63 & 20 & 17 \\
\hline $\begin{array}{l}\text { 3. I need instruction on the appropriate use of } \\
\text { transition words (e.g. "moreover"). }\end{array}$ & 77 & 7 & 16 \\
\hline $\begin{array}{l}\text { 4. I need instruction on the complete development of } \\
\text { the topic. }\end{array}$ & 50 & 27 & 13 \\
\hline $\begin{array}{l}\text { 5. I need instruction on the logical development of } \\
\text { my ideas. }\end{array}$ & 47 & 23 & 30 \\
\hline $\begin{array}{l}\text { 6. I need instruction on appropriate dividing of } \\
\text { paragraphs. }\end{array}$ & 70 & 10 & 20 \\
\hline 7. I need instruction on appropriate tense use. & 71 & 10 & 9 \\
\hline $\begin{array}{l}\text { 8. I need instruction on correct preposition use (e.g. } \\
\text { "with"). }\end{array}$ & 67 & 17 & 16 \\
\hline $\begin{array}{l}\text { 9. I need instruction on correct article use ("a", "an", } \\
\text { "the"). }\end{array}$ & 70 & 7 & 23 \\
\hline 10. I need instruction on the grammar of sentences. & 71 & 19 & 10 \\
\hline 11. I need instruction on correct spelling. & 86 & 4 & 10 \\
\hline 12. I need instruction on correct punctuation. & 73 & 10 & 17 \\
\hline $\begin{array}{l}\text { 13. I need instruction on the appropriate use of } \\
\text { vocabulary to express ideas clearly. }\end{array}$ & 47 & 20 & 33 \\
\hline 14. I need instruction on the use of synonyms. & 47 & 27 & 26 \\
\hline 15. I need instruction on paraphrasing. & 57 & 10 & 33 \\
\hline $\begin{array}{l}\text { 16. I need instruction on the correct use of citation } \\
\text { (quoting an author). }\end{array}$ & 57 & 3 & 40 \\
\hline 17. I need instruction on how to avoid plagiarism. & 45 & 7 & 48 \\
\hline
\end{tabular}

The sub-research question of the second research question was pertinent to their tendencies about the types of AW activities. As seen in Figure 3, in AW classes, they expected to engage in a range of activities that encourage them to write long academic papers ( $77 \%$ ), to review and analyze examples of academic writing (e.g. theses; research articles) (73\%), and to improve their AW skills and practices $(63 \%)$. They relied on themselves about punctuation (10\%) and grammar issues (10\%) and they did not prefer to take part in activities emphasizing them. Likewise, Cai (2017) found that reviewing and making criticism of the previous research are one of the most challenging AW skills while they felt secure about grammar. Alhashemi, AlSubaeie, and Shukri, (2017) found that nonnative postgraduate 
students of English expected to participate in writing activating activities to produce long academic texts.

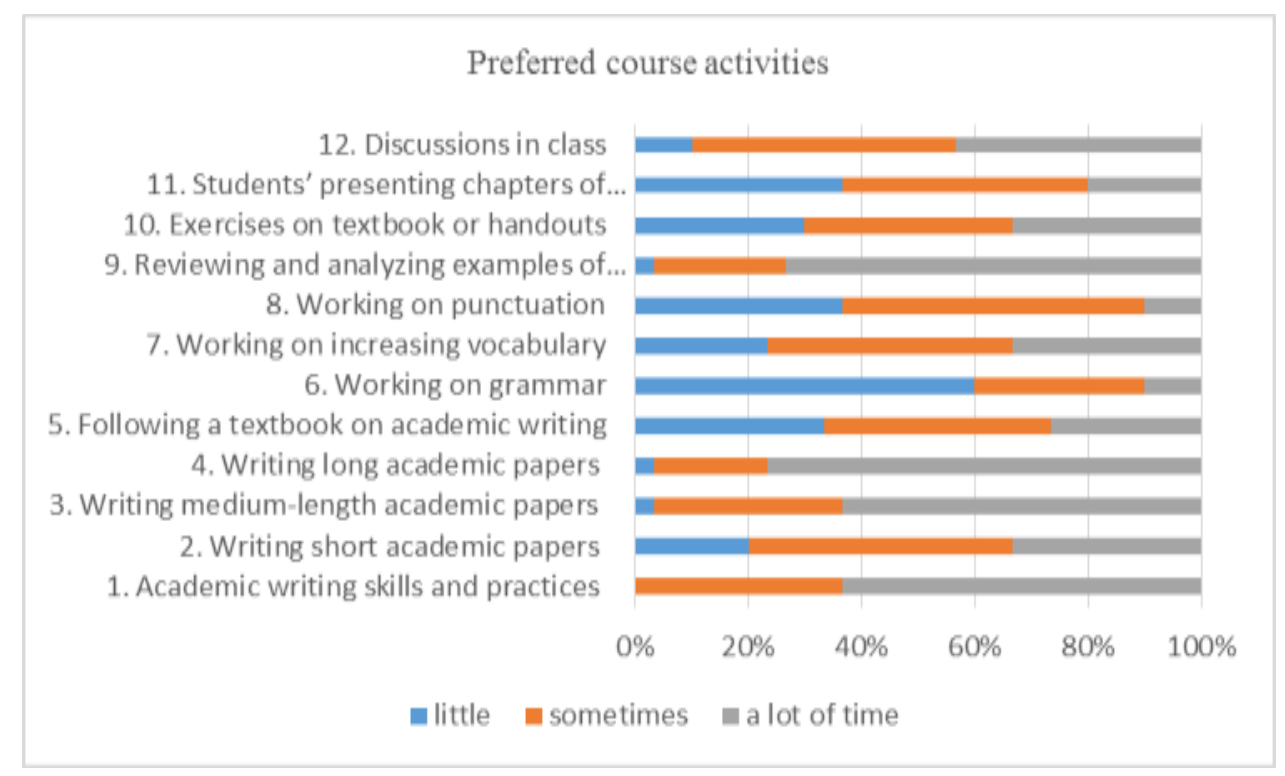

Figure 3. Preferred course activities

AW requires critical thinking and making choices on a wide range of issues such as choosing appropriate words, styles, referencing, etc. Through reviewing and analyzing examples, postgraduate students may move from vague sense of AW conventions of their disciplines and make explicit choices to organize their texts, pull their readers into text and mitigate their stance. The received knowledge gathered from such kinds of activities may be employed while writing long AW texts like research articles, response papers and reviews.

The fourth research question aimed to figure out whether there was a statistically significant difference between MA and PhD students about their academic needs. To do this, an independentsamples t-test was conducted. The items that were found to be significant were: writing a thesis $(\mathrm{MD}=$ $1.33, \mathrm{SD}=.41, \mathrm{p}=.003$, Cohen's $\mathrm{d}=1.2)$ and writing a term paper $(\mathrm{MD}=1.2, \mathrm{SD}=.46, \mathrm{p}=.013$, Cohen's $\mathrm{d}=0.3$ ) in terms of genre-based needs; writing comprehensive literature reviews ( $\mathrm{MD}=1.1, \mathrm{SD}=.45$, $\mathrm{p}=.016$, Cohen's $\mathrm{d}=0.3$ ) and writing clear methodology sections $(\mathrm{MD}=1.0, \mathrm{SD}=46, \mathrm{p}=.037$, Cohen's $\mathrm{d}=0.2$ ) associated with their needs about the parts of academic texts, exercises on textbook or handouts $(\mathrm{MD}=.46, \mathrm{SD}=.18, \mathrm{p}=014$, Cohen's $\mathrm{d}=0.5)$, discussion in class $(\mathrm{MD}=.60, \mathrm{SD}=.25, \mathrm{p}=025$, Cohen's $\mathrm{d}=2.4$ ) regarding the activities they preferred to engage in AW classes. The effect size was large for the level of the differences across two items: writing a thesis and discussion in class, which proved the strength of the difference between these two groups.

Apparently, $\mathrm{PhD}$ and MA students in our study shared mostly the same academic writing needs. The significant difference about writing a thesis might be attributed to the fact that doctoral dissertations are the milestones in the academic career of postgraduate students. Hence, they have different needs on the production of their doctoral dissertations to make a substantial and original contribution to their field. MA students are usually more focused on their term papers. In a way, they need guidance on how to approach their assignments, and grasp the academic expectations of their disciplines. It is likely that they consider discussion activities as an effective means of getting the norms of their academic culture. For Hyland (2009), doctoral and masters are different pathways. The first is a long journey of being a competent member of an academic community, while the latter helps to gain additional qualification in a particular profession. 


\section{Conclusions}

In the context of English-medium global academic world and focused attention on gaining credibility in this world through various academic genres written in English, academic writing courses are of importance for post-graduate students of English. The analysis of AW needs of 30 post-graduate students studying in the departments of English Language Teaching and English Language and Literature is a point of departure in this study for determining their AW needs and what should be included in AW courses designed for them. We first highlighted some of the ways in which postgraduate students of English consider AW. Their views of AW were contextualized in relation to particular dimensions of AW: linguistic conventions of the disciplines and readers. What was missing in their views was the negotiation of authorial stance in academic genres, which wields power in being a credible academic.

Their AW needs were intended to examine through various points of views in the present study. In terms of academic genres, there was a particular need of instruction on writing a thesis, a book review, a research article and a conference speech. Regarding their needs about the moves of academic texts, there was a relative emphasis on writing discussions, writing findings with clarity and writing clear methodology sections. Specific language problems took up the following issues: avoiding plagiarism, the correct use of citation, paraphrasing and the appropriate use of vocabulary. Activities that focus on writing long academic papers, reviewing and analyzing examples of academic writing (e.g. theses; research articles) and improving their AW skills and practices have the potential for the post-graduate students of English to enhance their AW skills.

The results of this study have pedagogical implications. It is difficult to teach AW skills without developing awareness of what AW is regarding cultural, disciplinary and linguistic aspects. The second step may be to introduce the linguistic features of AW such as lexical bundles and metadiscourse. Some prominent issues such as referencing and plagiarism may also be taken into consideration. Then a genrebased approach to teach AW may be followed for AW consists of various genres that have different linguistic conventions based on the discipline and culture. Students may analyze linguistic features of each academic genre and then produce their own texts. The most common linguistic features associated with the moves of each genre (abstract, introduction, methodology, etc) can be a component of this approach. Specialized corpora comprised of authentic academic genres may provide effective materials needed to adapt this approach.

AW is more closely related to engagement and stance, as Hyland (2005c) claims. That is, academics modalize the content and their claims to construct their stance and communicate with readers. Thus, academic writing courses should draw fine distinctions among the organizational issues, stance and engagement and develop post-graduate students' awareness of using linguistic devices appropriately to maintain disciplinary-specific and genre-based dimensions of AW. Hyland (2005a) suggests that EAP teachers are responsible for demystifying the norms of academic discourse to guide their students to overcome the challenges of being a member of their disciplines through gaining control over writing.

Hyland (2005b) offers a particular approach called rhetorical consciousness raising approach to teach metadiscourse, which is a linguistic device of AW. It is likely that this approach may brilliantly capture all dimensions of AW. The key elements of it are the considerations of:

1. the writers' target needs

2. the writers' prior writing and the learning experiences

3. the role of language in expressing function

4. the importance of social interactions

5. the use of authentic texts 
6. the role of audience and community practices (p. 181).

This approach includes three main steps: making writers' linguistic strategies clear, creating opportunities for students to use and create their own texts.

This study is limited to data gathered from one stakeholder, postgraduate students of English. Future studies that gather information from all stakeholders such as EAP teachers giving the course and the head of the departments would give more insights about the AW needs of post-graduate students and may provide a base for academics to conduct AW courses that is based on the real needs of their students.

\section{Ethics Committee Approval}

The author(s) confirm(s) that the study does not need ethics committee approval according to the research integrity rules in their country (Date of Confirmation: December 23, 2019).

\section{References}

Al-Hashemi, B. I., AlSubaeie, M. S., \& Shukri, N. A. (2017). Academic writing needs of TESOL postgraduate in the Saudi context. International Journal of English Language Education, 5(2), 151163. Doi: $10.5296 /$ ijele.v5i2.12235

Al-Khasawneh, F. M. S., \& Maher, S. (2010). Writing for academic purposes: Problems faced by Arab postgraduate students of the college of business, UUM. ESP World, 9(2), 1-23.

Bitchener, J., \& Basturkmen, H. (2006). Perceptions of the difficulties of postgraduate L2 thesis students writing the discussion section. Journal of English for Academic Purposes, 5(1), 4-18.

Bolarinwa O. A. (2015). Principles and methods of validity and reliability testing of questionnaires used in social and health science researches. Niger Postgrad Med J, 22, 195-201.

Brown, J. D. (1995). The elements of language curriculum. Massachusetts: Heinle \& Heinle Publishers.

Buckingham, L. (2008). Development of English academic writing competence by Turkish Scholars. International Journal of Doctoral Studies, 3, 1-18.

Burke, S. B. (2010). The construction of writer identity in the academic writing of Korean ESL students: A qualitative study of six Korean students in the U.S. (Unpublished doctoral dissertation). Indiana University of Pennsylvania, Indiana.

Cai, L. J. (2017). Students' perceptions of academic writing: A needs analysis of EAP in China. In K. Kimura \& J. Middlecamp (Eds.), Asian-focused ELT research and practice: Voices from the far edge (p. 127-151). Cambodia: Phnom Penh.

Cameron, C., Nairn, K., \& Higgins, J. (2009). Demystifying academic writing: reflections on emotions, know-how and academic identity. Journal of Geography in Higher Education, 33(2), 269-284. Doi: $10.1080 / 03098260902734943$

Chou, C. (1998). Evaluation and Needs Analysis of an Academic Writing Course for International Graduate Students: ELI 83.

Feak, C. B. (2016). EAP supports for postgraduate students. In K. Hyland \& P. Shaw (Eds.), The Routledge handbook of English for academic purposes (p. 489-501). London: Routledge.

Huang, L. S. (2010). Seeing eye to eye? The academic writing needs of graduate and undergraduate students from students' and instructors' perspectives. Language Teaching Research, 14(4), 517-539. 
Hyland, K. (2001). Bringing in the reader. Written Communication, 18(4), 529-574.

Hyland, K. (2002). Authority and invisibility: Authorial identity in academic writing. Journal of Pragmatics, 34, 1081-1112.

Hyland, K. (2004). Disciplinary discourses: Social interactions in academic writing. The USA: The University of Michigan Press.

Hyland, K. (2009). Academic discourse. London: Cambridge University Press.

Hyland, K. (2010). Community and individuality: Performing identity in Applied Linguistics. Written Communication, 27(2), 159-188. Doi: 10.1177/0741088309357846

Hyland, K. (2005a). Patterns of engagement: dialogic features and L2 graduate writing. In L. J. Ravelli \& R. A. Ellis (Eds.), Analyzing academic writing (p. 5-23). Cornwall, Continuum.

Hyland, K. (2005b). Metadiscourse: Exploring interaction in writing. London: Continuum.

Hyland, K. (2005c). Stance and engagement: A model of interaction in academic discourse. Discourse Studies, 7(2), 173-192. Doi: 10.1177/1461445605050365

Irvin, L. L. (2010). What is "academic" writing? Writing spaces: Readings on Writing, 1.

Retrieved from http://wac.colostate.edu/books/writingspaces1/irvin--what-is-academic-writing.pdf

Klimova, B. F. (2015). Designing an EAP Course. Procedia-Social and Behavioral Sciences, 191, 634638.

King, N. \& Horrocks, C. (2010). Interviews in qualitative research. Cornwall: MPG Books Group.

Li, L. Y., \& Vandermensbrugghe, J. (2011). Supporting the thesis writing process of international research students through an ongoing writing group. Innovations in Education and Teaching International, 48(2), 195-205.

Long, M. (2005). Second language needs analysis. Cambridge: Cambridge University Press.

Ma, X. (2018). L2 postgraduate students' conceptions of English academic writing: Perspectives of mainland Chinese students. The Asian Journal of Applied Linguistics, 5(1), 81-82.

Murray, M., \& Moore, S. (2006). The handbook of academic writing. Berkshire: Open University Press.

Pallant, J. (2005). SPSS survival manual. Sydney: Allen \& Unwin.

Sağlamel, H. \& Kayaoğlu, M. N. (2015). English major students' perceptions of academic writing: A struggle between writing to learn and learning to write. Journal of History Culture and Art Research 4(3), 37-52. Doi: 10.7596/taksad.v4i3.477.

Tait, J. (1999). Multiple Perspectives on Academic Writing Needs. Paper presented at 33rd Annual TESOL Convention, (p.1-20). NY, March 1999. Retrieved from https://files.eric.ed.gov/fulltext/ED432157.pdf 


\section{Appendix A. An example appendix}

\section{ELT Postgraduate Students' Expectations of Academic Writing Courses}

Dear participant,

We would like to invite you to respond to the questions in the following questionnaire. It is designed to elicit expectations you have about an academic writing course as a part of your postgraduate programme. Please note that we are interested in your views, so there are no wrong answers. Your responses will remain confidential and not shared with any third parties. Thank you in advance for your responses.

\section{Section 1: About yourself}

1. Your age:

2. Your gender:

3. Your first language:

4. The university where you study:

5. The programme you attend:

6. Number of years in postgraduate programmes:

7. Would you like to take up in a following interview? Please write your email address here:

\section{Section 2: General Questions}

1. What is your definition of academic writing?

2. How do you feel about academic writing?

\section{Section 3: Kinds of academic writing/audience}

What kinds of writing in English do you expect to do in the future?

\begin{tabular}{|l|l|l|l|l|l|}
\hline & $\begin{array}{l}1 \\
\text { Strongly } \\
\text { disagree }\end{array}$ & $\begin{array}{l}2 \\
\text { Disagree }\end{array}$ & $\begin{array}{l}\text { Neutral } \\
\text { 1. I need instruction on writing a thesis. }\end{array}$ & & $\begin{array}{l}\text { Agree } \\
\text { Strongly agree }\end{array}$ \\
\hline 2. I need instruction on writing research article. & & & & \\
\hline 3. I need instruction on writing a book review. & & & & & \\
\hline 4. I need instruction on writing a term paper. & & & & \\
\hline 5. I need instruction on writing a response paper. & & & & \\
\hline 6. I need instruction on preparing a conference speech. & & & & & \\
\hline 7. I need instruction on preparing a poster. & & & & & \\
\hline
\end{tabular}

8. Do you think about the readers when you are writing an academic paper? Please explain.

Section 4: Parts in academic texts

\begin{tabular}{|c|c|c|c|c|c|}
\hline & $\begin{array}{l}1 \\
\text { Strongly } \\
\text { disagree }\end{array}$ & $\begin{array}{l}2 \\
\text { Disagree }\end{array}$ & $\begin{array}{l}3 \\
\text { Neutral }\end{array}$ & $\begin{array}{l}4 \\
\text { Agree }\end{array}$ & $\begin{array}{l}5 \\
\text { Strongly } \\
\text { agree }\end{array}$ \\
\hline 1. I need instruction on choosing an appropriate title. & & & & & \\
\hline 2. I need instruction on writing concise abstracts. & & & & & \\
\hline 3. I need instruction on writing effective introductions. & & & & & \\
\hline $\begin{array}{l}\text { 4. I need instruction on writing comprehensive literature } \\
\text { reviews. }\end{array}$ & & & & & \\
\hline $\begin{array}{l}\text { 5. I need instruction on writing clear methodology } \\
\text { sections. }\end{array}$ & & & & & \\
\hline 6. I need instruction on writing findings with clarity. & & & & & \\
\hline 7. I need instruction on writing discussions & & & & & \\
\hline 8. I need instruction on writing logical conclusions. & & & & & \\
\hline $\begin{array}{l}\text { 9. I need instruction on writing implications and } \\
\text { suggestions. }\end{array}$ & & & & & \\
\hline 10. I need instruction on writing the reference section. & & & & & \\
\hline
\end{tabular}


11. Do you have problems in writing parts of academic texts not mentioned above? Please specify.

\section{Section 5: Specific language areas}

\begin{tabular}{|c|c|c|c|c|c|}
\hline & $\begin{array}{l}1 \\
\text { Strongly } \\
\text { disagree }\end{array}$ & $\begin{array}{l}2 \\
\text { Disagree }\end{array}$ & $\begin{array}{l}3 \\
\text { Neutral }\end{array}$ & $\begin{array}{ll}4 \\
\text { Agree }\end{array}$ & $\begin{array}{l}5 \\
\text { Strongly } \\
\text { agree }\end{array}$ \\
\hline $\begin{array}{l}\text { 1. I need instruction on using topic sentences } \\
\text { in paragraphs. }\end{array}$ & & & & & \\
\hline $\begin{array}{l}\text { 2. I need instruction on giving enough } \\
\text { supporting details or examples in body } \\
\text { paragraphs. }\end{array}$ & & & & & \\
\hline $\begin{array}{l}\text { 3. I need instruction on the appropriate use of } \\
\text { transition words (e.g. "moreover"). }\end{array}$ & & & & & \\
\hline $\begin{array}{l}\text { 4. I need instruction on the complete } \\
\text { development of the topic. }\end{array}$ & & & & & \\
\hline $\begin{array}{l}\text { 5. I need instruction on the logical } \\
\text { development of my ideas. }\end{array}$ & & & & & \\
\hline $\begin{array}{l}\text { 6. I need instruction on appropriate dividing of } \\
\text { paragraphs. }\end{array}$ & & & & & \\
\hline 7. I need instruction on appropriate tense use. & & & & & \\
\hline $\begin{array}{l}\text { 8. I need instruction on correct preposition use } \\
\text { (e.g. "with"). }\end{array}$ & & & & & \\
\hline $\begin{array}{l}\text { 9. I need instruction on correct article use ("a", } \\
\text { "an", "the"). }\end{array}$ & & & & & \\
\hline $\begin{array}{l}\text { 10. I need instruction on the grammar of } \\
\text { sentences. }\end{array}$ & & & & & \\
\hline 11. I need instruction on correct spelling. & & & & & \\
\hline 12. I need instruction on correct punctuation. & & & & & \\
\hline $\begin{array}{l}\text { 13. I need instruction on the appropriate use of } \\
\text { vocabulary to express ideas clearly. }\end{array}$ & & & & & \\
\hline 14. I need instruction on the use of synonyms. & & & & & \\
\hline 15. I need instruction on paraphrasing. & & & & & \\
\hline $\begin{array}{l}\text { 16. I need instruction on the correct use of } \\
\text { citation (quoting an author). }\end{array}$ & & & & & \\
\hline $\begin{array}{l}\text { 17. I need instruction on how to avoid } \\
\text { plagiarism. }\end{array}$ & & & & & \\
\hline
\end{tabular}

18. Are there any other language areas you have difficulties in? Please specify.

\section{Section 6: Course activities}

\begin{tabular}{|c|c|c|c|}
\hline & \multicolumn{3}{|c|}{ requested frequency } \\
\hline & little & sometime & a little time \\
\hline $\begin{array}{l}\text { 1. Academic writing skills and practices (e.g. citation, paraphrasing, } \\
\text { summarizing) }\end{array}$ & & & \\
\hline 2. Writing short academic papers (1-4 pages) & & & \\
\hline 3. Writing medium-length academic papers (5-9 pages) & & & \\
\hline 4. Writing long academic papers (10 or more pages) & & & \\
\hline 5. Following a textbook on academic writing & & & \\
\hline 6. Working on grammar & & & \\
\hline 7. Working on increasing vocabulary & & & \\
\hline 8. Working on punctuation & & & \\
\hline $\begin{array}{l}\text { 9. Reviewing and analyzing examples of academic writing (e.g. theses; } \\
\text { research articles) }\end{array}$ & & & \\
\hline
\end{tabular}




\begin{tabular}{|l|l|l|l|}
\hline 10. Exercises on textbook or handouts & & & \\
\hline 11. Students' presenting chapters of textbooks in class & & & \\
\hline 12. Discussions in class & & & \\
\hline
\end{tabular}

13. Others (please specify)

This is the end of the survey. Thank you very much for your participation.

\section{Lisansüstü öğrencilerin ihtiyaçlarını belirleme: Akademik yazım derslerinin ilk aşamas1}

\section{$\ddot{O} \mathbf{z}$}

Akademik yazım çalışmaları öğrencilerin akademik toplumun beklentilerini karşılamak amacıyla disiplin normlarını öğrenmelerinin temel alındığı bir süreçtir. Bu nedenle akademik yazım dersleri bu normlara değinmelidir. Bu derslerin en önemli gereksinimlerinden biri öğrencilerin ihtiyaçları ve akademik toplumun beklentilerine uygun bir program hazırlamak amacıyla bu ihtiyaçları belirlemektir. Bu çalışmanın amacı Likerttipli ve açık uçlu sorulardan oluşan çevrimiçi bir anket yoluyla İngilizce Öğretmenliği ve İngiliz Dili ve Edebiyatı bölümlerindeki lisansüstü ögrencilerin akademik yazım ihtiyaçlarını belirlemektir. Likert-tipi sorular betimleyici istatistik ve t-test kullanılarak analiz edilirken, açık uçlu soruların analizinde tematik analiz uygulanmıştır. Çalışmanın sonucunda katılımcıların (30 Türk lisansüstü öğrenci) akademik yazımda disiplin normları ve okuyucularıyla iletişimin önemine dair bilgi sahibi oldukları fakat yazar duruşu ile ilgili farkındalık geliştirmedikleri belirlenmiş̧ir. Yüksek lisans ve doktora öğrencilerinin akademik yazım ihtiyaçları arasında istatistiksel bir fark bulunmamıştır. Lisansüstü akademik yazım dersleri öğrencilerin ihtiyaçlarını karşılamak amacıyla ihtiyaç temelli müfredatlar geliştirilmelidir.

Anahtar sözcükler: lisansüstü programlar; akademik yazım; ihtiyaç analizi

\section{AUTHOR BIODATA}

Fatma Yuvayapan is an assistant professor at the Department of Translation and Interpreting at Kahramanmaraş İstiklal University. She earned her MA on teacher education in 2013 and her PhD on corpus linguistics in 2018. Her research interest includes English language teaching, corpus linguistics with a particular reference to academic writing and pragmatics. She has been teaching English since 2003.

Hayriye Bilginer is an assistant professor at the Department of English Language and Literature at Kahramanmaraş Sütçü İmam University. She earned her PhD at the Department of German Language and Literature at Hacettepe University. She is interested in German and English Literature and Linguistics. 